\title{
O PROJETO PEDAGÓGICO CURRICULAR DE UM CURSO DE LICENCIATURA EM QUÍMICA: EM BUSCA DA LEI 10.639/03
}

\author{
José Guilherme Martins Siqueira1; Vanessa Pires²; Liliam Quelem \\ Tavares $^{3}$; Priscila Afonso Rodrigues de Sousa ${ }^{4}$.
}

\section{Resumo}

A lei 10.639/03 surgiu diante da necessidade de garantir o devido espaço aos temas relacionados a cultura afro-brasileira, alterando as Diretrizes e Bases da Educação Nacional, tornando, então, obrigatório o estudo sobre a cultura e história africana e afro-brasileira nas instituições públicas e privadas de ensino. Sendo assim, os conteúdos abordados na disciplina de química devem ultrapassar os conceitos que envolvem aspectos: sociais, políticos, históricos, filosóficos e culturais, através de uma prática pedagógica eficiente que desperte a reflexão do futuro professor, proporcionando assim um ensino mais interdisciplinar, indo além dos conceitos químicos, trabalhando também com história, geografia, sociologia e literatura. Neste contexto, este trabalho tem por objetivo identificar e analisar a presença da Lei 10.639/03, no Curso de Licenciatura em Química da Universidade Federal de Goiás - Regional Catalão, por meio do Projeto Pedagógico do Curso (PPC). Para tanto utilizou-se pesquisa qualitativa documental, que se iniciou a partir das indagações sobre a abordagem da Lei Federal 10.639/03 no currículo de formação de professores do Curso de Química. Por estar fundamentado pela LDB e ter sido elaborado em 2010, o mesmo carece seguir a lei 10.639, uma vez que o saber sobre a lei é de grande importância para a formação docente inicial, pois é uma maneira de

\section{1}

Graduando pela Universidade Federal de Goiás - Regional Catalão, Brasil. guilhermejms22@hotmail.com

2

Graduada pela Universidade Federal de Goiás - Regional Catalão, Brasil.

3

Mestranda pela Universidade Federal de Goiás - Regional Catalão, Brasil.

4

Doutoranda pela Universidade Federal de Uberlândia - Campus Santa Monica, Brasil. 
trabalhar a interdisciplinaridade proporcionando aos alunos o alcance de uma melhor dimensão sobre as questões socioculturais, visto que o Curso objetiva-se a "garantir uma ampla fundamentação teórico-prática sobre as diversas áreas da química e suas relações com o meio ambiente, a sociedade, o cotidiano e a vida". Por ser uma ciência que se desenvolveu juntamente a humanidade, a química, assim como as demais licenciaturas, deve abordar a história e cultura africana e afro-brasileira, visando a formação de um profissional com visão ampla e reflexivo quanto aos problemas sociais presentes no meio em que vive. Observa-se que neste PPC não é abordado de forma direta a lei 10.639/03, apesar do mesmo salientar que será possibilitado ao estudante "oportunidade de diversificar e enriquecer sua formação por meio da sua participação em tipos variados de programas acadêmicos extraclasse, como por exemplo, iniciação científica, participação em projetos de extensão". Tais projetos, se bem elaborados, contribuiria para que a lei estivesse presente na formação do licenciando. Ao final, pontua-se que o PPC, criado em 2010, deveria ter incluso essa lei em sua estrutura, já que o mesmo utiliza a LDB como fonte para organização de sua estrutura, demonstrando em várias partes a proposta do Curso em formar profissionais críticos e em consonância com a história da sociedade.

Palavras Chave: Formação inicial de professores; Ensino de química; Interdisciplinaridade no ensino. 